\title{
Abdominal Wall Endometriosis: Analysis of 66 Patients at a Tertiary Center
}

\begin{tabular}{|c|c|}
\hline \multicolumn{2}{|c|}{$\begin{array}{l}\text { (D) Besim Haluk Bacanakgil11, (D Hasene Özçam², (D) Mustafa Deveci1, (D Sezgi Güllü Yıldırım¹ } \\
\text { 1'istanbul Training and Research Hospital, Clinic of Obstetrics and Gynecology, İstanbul, Turkey } \\
\text { 2ístanbul Haseki Training and Research Hospital, Clinic of Obstetrics and Gynecology, İstanbul, Turkey }\end{array}$} \\
\hline ABSTRACT & ÖZ \\
\hline $\begin{array}{l}\text { Introduction: The objective of this study was to review the } \\
\text { patients' characteristics and surgical findings of surgically } \\
\text { excised abdominal wall endometriosis (AWE) cases. } \\
\text { Methods: We retrospectively analyzed the medical records } \\
\text { of patients diagnosed with AWE between } 2005 \text { and } 2015 \text {. } \\
\text { Descriptive data were collected and analyzed. }\end{array}$ & $\begin{array}{l}\text { Amaç: Çalışmamızın amacı, cerrahi olarak eksize edilmiş } \\
\text { abdominal duvar endometriozis (AWE) olgularının } \\
\text { hasta karakteristik özelliklerini ve cerrahi bulgularını } \\
\text { değerlendirmektir. } \\
\text { Yöntemler: 2005-2015 yılları arasında histopatolojik olarak } \\
\text { AWE tanısı alan hastaların tıbbi kayıtlarını retrospektif olarak } \\
\text { taradık ve tanımlayıcı dataları analiz ettik. }\end{array}$ \\
\hline $\begin{array}{l}\text { Results: Sixty-six patients with histopathological diagnosis of } \\
\text { AWE were included in our study. The mean age was } 32 \pm 6.8 \\
\text { years and all cases were multiparous. All patients had a history } \\
\text { of previous abdominal surgery and } 63 \text { patients had a history } \\
\text { of cesarean delivery. The primary symptom was a painful } \\
\text { palpable mass. The excised mass was generally on the previous } \\
\text { surgical scar. The excised mass location was observed as } \\
\text { subcutaneous tissue, fat layer, fascia and muscle tissue. There } \\
\text { was no statistical correlation depth of invasion and mass size }\end{array}$ & $\begin{array}{l}\text { Bulgular: Çalışmamıza histopatolojik AWE tanılı } 66 \text { hasta dahil } \\
\text { edildi. Ortalama yaş } 32,0 \pm 6,8 \text { idi ve tüm olgular multipar } \\
\text { idi. Altmış üç hastanın geçirilmiş abdominal cerrahi öyküsü } \\
\text { mevcuttu. Üç olgu hariç, tüm hastaların geçirilmiş sezaryen } \\
\text { öyküsü mevcuttu. Hastaların primer semptomu ağrı ve palpe } \\
\text { edilen kitle idi. Eksize edilen kitle genellikle önceki cerrahi skar } \\
\text { üzerindeydi. Eksize edilen kitle lokasyonu subkutan doku, yağ } \\
\text { tabakası, fasya ve kas dokusu olarak izlendi. Abdominal duvara } \\
\text { invazyon derinliği ve kitle boyutu ile geçirilmiş cerrahi sayısı } \\
\text { arasında bir ilişki izlenmedi. }\end{array}$ \\
\hline $\begin{array}{l}\text { with the number of previous surgeries. } \\
\text { Conclusion: Caesarean incision was considered as the most } \\
\text { important predisposing factor for AWE. As caesarean rates are } \\
\text { increasing, we believe that the incidence of AWE will increase } \\
\text { in the future. For this reason, more prospective studies are }\end{array}$ & $\begin{array}{l}\text { Sonuç: Sezaryen insizyonu, AWE için en önemli predispozan } \\
\text { faktör olarak değerlendirildi. Günümüzde sezaryen oranları } \\
\text { arttığı için, gelecekte abdominal duvar endometriozis } \\
\text { olgularının insidansının artacağına inanıyoruz. Bu nedenle } \\
\text { hastalığın prognozu ve profilaksisi iç̧in daha çok prospektif } \\
\text { çalıșmaya gereksinim duyulmaktadır. }\end{array}$ \\
\hline $\begin{array}{l}\text { needed tor prognosis and prophylaxis of the disease. } \\
\text { Keywords: Abdominal wall endometriosis, extrapelvic } \\
\text { endometriosis, incisional endometriosis, scar endometriosis }\end{array}$ & $\begin{array}{l}\text { Anahtar Kelimeler: Abdominal duvar endometriozis, } \\
\text { ekstrapelvik endometriozis, insizyonel endometriozis, skar } \\
\text { endometriozis }\end{array}$ \\
\hline
\end{tabular}

\section{Introduction}

Endometriosis is defined as the presence of endometrial glands and stroma outside the lining of the uterine cavity (1). Endometriosis is often found in intrapelvic areas such as ovaries, posterior cul de sac, ligaments of uterus, pelvic periton, rectovaginal septum, but it may rarely be in extrapelvic regions such as urinary tract, gastrointestinal tract and thorax $(2,3)$. The abdominal wall endometriosis (AWE) is an uncommon clinical entity with a reported incidence of $0.03-3.5 \%$ (4). This condition may develop spontaneously, however, the most important risk factor is previous surgeries $(5,6)$.

The purpose of our study was to investigate the demographic characteristics, surgical history, symptoms, diagnostic methods and intraoperative findings of patients with AWE and to make proposals for implementation.
Address for Correspondence/Yazıșma Adresi: Mustafa Deveci, İstanbul Training and Research Hospital, Clinic of Obstetrics and Gynecology, İstanbul, Turkey

Phone: +90 2124596000 E-mail: mustafa.deveci@gmail.com ORCID ID: orcid.org/0000-0003-4061-8414

Cite this article as/Atıf: Bacanakgil BH, Özçam H, Deveci M, Yıldırım SG. Abdominal Wall Endometriosis: Analysis of 66 Patients at a Tertiary Center. İstanbul Med J 2019; 20(2): 94-7.

(c) Copyright 2019 by the Istanbul Training and Research Hospital/Istanbul Medical Journal published by Galenos Publishing House. (C) Telif Hakkı 2019 Istanbul Ĕgitim ve Araștırma Hastanesi/istanbul Tıp Dergisi, Galenos Yayınevi tarafından basılmıștır.
Received/Geliș Tarihi: 06.06.2017 Accepted/Kabul Tarihi: 06.06.2018 


\section{Methods}

This is a retrospective descriptive case study. We reached the records of patients between November 2005 and March 2015 who had definitive histopathological diagnosis of AWE or scar endometriosis after surgical resection. Age, gravidity, parity, surgical history and characteristics of patients, diagnostic methods, and characteristics of the masses (e.g. number, localization, associated anatomical structures) were recorded. The time interval between the previous surgery and the diagnosis of AWE was defined as the "recognition period". Patients with intraabdominal organ endometriosis were excluded from study.

This study has been approved by İstanbul Training and Research Hospital Ethics Committee (decision no: 649, date: 15.05.2015). Every patient admitted to our clinic had signed informed consent for admission and we are allowed to investigate clinical data unless we use personal data.

\section{Statistical Analysis}

Statistical analysis was performed using SPSS for Windows version 15.0. Descriptive statistics were reported as number and percentage for categorical data, and mean, standard deviation, minimum and maximum for numerical variables. The trend for rate increase was examined with Mantel-Haenszel linear-by-linear association in chisquare test. Statistical significance level was considered as $p<0.05$.

\section{Results}

Sixty-six patients with histopathological AWE were included in our study (Table 1). The mean age was $32 \pm 6.8$ years. All cases were multiparous. The recognition period for AWE ranged from 2 to 24 years. Majority of the patients had a history of cesarean delivery. Almost all of the patients had Pfannenstiel incision scar. Major presenting symptoms were palpable mass and pain. Ultrasonography (US) (44\%), magnetic resonance imaging (MRI) (12\%), computed tomography (CT) (4.5\%) and fine-needle aspiration (FNA) (20\%) had been performed for preoperative diagnosis. Thirteen of the patients (20\%) had no preoperative diagnostic procedure and the masses were detected incidentally. The masses were mostly located at the previous surgery scars. In five patients, the masses were at umbilicus and far from previous scar. Sixty-nine percent of the masses were located at the incision corners. The endometriotic masses were mostly located in the subcutaneous tissue (45.5\%). The mean mass size was $28.7 \pm 10.4 \mathrm{~mm}$. The masses were completely excised in all patients. Polypropylene mesh graft was used in one patient. There was no statistically significant relationship between mass location and number of cesarean sections $(p=0.744)$ (Table 2). There was no significant relationship between endometriotic mass size and the number of cesarean sections ( $p=0.197$ ) (Table 3).

\section{Discussion}

latrogenic implantation theory is the most widely accepted theory for AWE. According to this theory, it is suggested that endometrial cells are planted directly at the incision $(7,8)$. The development of endometriotic implants/masses mostly in previous gynecologic scars (such as cesarean section, hysterotomy, hysterectomy) supports iatrogenic implantation theory (6,9). Metaplasia and migration theories are other accepted theories in the development of

\begin{tabular}{|c|c|c|c|}
\hline & & Range & Mean \pm SD \\
\hline \multicolumn{2}{|l|}{ Age (year) } & $19-51$ & $32.0 \pm 6.8$ \\
\hline \multicolumn{2}{|c|}{ The recognition period (month) } & $2-24$ & $5.6 \pm 4.1$ \\
\hline & & $\mathbf{n}$ & $\%$ \\
\hline \multirow{5}{*}{ Surgery history } & One cesarean section & 32 & 48.5 \\
\hline & Two cesarean sections & 23 & 34.8 \\
\hline & Three cesarean sections & 8 & 12.1 \\
\hline & Ovarian cystectomy & 2 & 3.0 \\
\hline & Hysterectomy & 1 & 1.5 \\
\hline \multirow{2}{*}{ Shape of incision } & Transvers (Pfannenstiel) & 65 & 98.5 \\
\hline & Midline & 1 & 1.5 \\
\hline \multirow{2}{*}{ Symptoms and findings } & Palpable mass & 43 & 65.2 \\
\hline & Pain & 23 & 34.8 \\
\hline \multirow{5}{*}{ Preoperative imaging } & US & 29 & 43.9 \\
\hline & MRI & 8 & 12.1 \\
\hline & $\mathrm{CT}$ & 3 & 4.5 \\
\hline & FNA & 13 & 19.7 \\
\hline & None & 13 & 19.7 \\
\hline \multirow{15}{*}{ AWE mass } & \multicolumn{3}{|l|}{ Region } \\
\hline & Previous scar & 61 & 92.4 \\
\hline & Umbilicus & 5 & 7.6 \\
\hline & \multicolumn{3}{|l|}{ Site (Pfannenstiel) } \\
\hline & Left corner & 26 & 39.4 \\
\hline & Right corner & 20 & 30.3 \\
\hline & Middle & 15 & 22.7 \\
\hline & \multicolumn{3}{|l|}{ Location } \\
\hline & Subcutaneous tissue & 30 & 45.5 \\
\hline & Muscular & 23 & 34.8 \\
\hline & Fascia & 9 & 13.6 \\
\hline & Fat & 4 & 6.1 \\
\hline & & Range & Mean \pm SD \\
\hline & Number & $1-2$ & $1.0 \pm 0.1$ \\
\hline & Size (mm) & $11-55$ & $28.7 \pm 10.4$ \\
\hline
\end{tabular}

Table 2. The relationship between the number of cesarean sections and the mass localization

\begin{tabular}{|l|l|l|l|}
\hline & \multicolumn{3}{|l|}{ Number of cesarean, $\mathbf{n}(\%)$} \\
\hline Mass location & One & Two & Three \\
\hline Subcutaneous tissue & $18(56.3)$ & $9(39.1)$ & $3(37.5)$ \\
\hline Fat & $1(3.1)$ & $1(4.3)$ & $1(12.5)$ \\
\hline Fascia & $2(6.3)$ & $3(13.0)$ & $4(50.0)$ \\
\hline Muscular & $11(34.4)$ & $10(43.5)$ & $0(0.0)$ \\
\hline$p=0.744$ & & & \\
\hline
\end{tabular}




\begin{tabular}{l}
$\begin{array}{l}\text { Table 3. The relationship between the number of cesarean } \\
\text { sections and mass size }\end{array}$ \\
\begin{tabular}{|l|l|}
\hline Cesarean number & $\begin{array}{l}\text { Diameter of mass } \\
\text { Mean } \pm \text { SD }(\mathbf{m m})\end{array}$ \\
\hline One & $27.0 \pm 9.9$ \\
\hline Two & $29.9 \pm 11.6$ \\
\hline Three & $33.6 \pm 9.1$ \\
\hline SD: standard deviation, $p=0.197$ & \\
\hline
\end{tabular} \\
\hline
\end{tabular}

extrapelvic endometriosis $(9,10)$. Metaplasia theory claims that the differentiation of primitive mesenchymal cells into endometrial cells in the scar tissue causes endometriosis. The migration theory claims lymphatic or vascular spread of endometrial cells to distant sites. The nodules in previously non-operated patients or nodules in distant locations can be explained by this theory. None of these theories can exactly explain the whole case. Therefore, some researchers claim that genetic and environmental factors together play a role in the etiology of endometriosis (11). Cesarean section is one of the most common causes of AWE $(2,6)$. The incidence of AWE in cesarean scar has been reported to between $0.03-1.08 \%$. In the studies of Khamechian et al. (2) and Ding and Zhu (6), all patients had a history of cesarean section.

AWE usually develops in women of reproductive age $(10,12)$. Predominantly, the patients are multiparous. Palpable mass is seen in $63-100 \%$ and pain in $41-92.5 \%(2,6,9,13)$. The increase in mass size during menstruation is pathognomonic for scar endometriosis $(9,14)$. In our study, most common finding was palpable mass $(65 \%)$. In the differential diagnosis, hernia, suture granuloma, primary or metastatic tumors, sarcoma, cysts, nodular and proliferative fasciitis, fat necrosis, lipoma, abscess or hematoma of the abdominal wall should be considered $(14,15)$. US, CT and MRI can be used in the diagnosis and US is the primary imaging method to be preferred. The endometriotic masses are mostly vascularized and hypoechoic sonographically. CT and MRI provide useful information about the anatomic location of the mass in the abdominal wall and its relation with neighboring structures for preoperative evaluation. However, imaging findings are not specific $(12,16)$. Definitive diagnosis is possible only histopathologically $(2,17)$. Some authors recommend FNA cytology before surgical excision. Observation of endometrial gland, stroma and hemosiderin-laden macrophages in cytology are considered diagnostic findings $(15,18,19)$. On the other hand, there is no consensus for FNA, because there is some risk of planting endometrial cells to the puncture site $(9,20)$.

Local wide surgical excision is the primary treatment for AWE. For both treatment and reducing the risk of lesion recurrence, the mass should be widely excised with at least $1 \mathrm{~cm}$ margin $(6,21)$. After surgical excision, defect can be repaired by using autologous or synthetic graft according to the width of the defect and its anatomical localization $(11,22)$. Postoperative adjuvant hormone therapy such as danazol, progesterone and GnRH analogs are recommended for patients with concomitant pelvic endometriosis or recurrent AWE $(21,23)$.

\section{Study Limitations}

The major limitations of our study were retrospective nature and failure of post-treatment controls due to inability to reach the majority of patients.

\section{Conclusion}

Endometriosis should be considered in differential diagnosis of a painful mass in anterior abdominal wall, especially in women with a history of pelvic or obstetric surgery. According to our findings and the literature $(2,4,6-14,24,25)$, previous cesarean section is the most well known risk factor in etiology. This suggests that the disease is highly caused by iatrogenic sowing. For this reason, the following recommendations will contribute to non-occurrence of AWE after cesarean sections; intraoperatively, a) rapid removal of the gauze used to clean uterine cavity and ensure no contact to the incision, b) replacement of gloves after uterine incision suturing, c) washing of the abdominal wall tissues with physiological saline after the uterus is closed, d) not using of remaining uterine suture materials elsewhere, e) irrigation of incision with physiological saline after the parietal peritoneum is closed. These recommendations can considerably reduce the incidence of AWE.

Ethics Committee Approval: This study has been approved by İstanbul Training and Research Hospital Ethics Committee (decision no: 649, date: 15.05.2015).

Informed Consent: Every patient admitted to our clinic had signed informed consent for admission.

Peer-review: Externally and internally peer-reviewed.

Author Contributions: Concept - B.H.B., H.Ö.; Design - S.G.Y.; Supervision - B.H.B., H.Ö., Resources - M.D., S.G.Y.; Data Collection and/or Processing - B.H.B., M.D.; Analysis and/or Interpretation - H.Ö., S.G.Y.; Literature Search - B.H.B.; Writing Manuscript - M.D.; Critical Review - B.H.B., H.Ö.

Conflict of Interest: The authors have no conflict of interest to declare.

Financial Disclosure: The authors declared that this study has received no financial support.

\section{References}

1. Accetta I, Accetta P, Accetta AF, Maia FJ, Oliveira AP. Abdominal wall endometrioma. Rev Col Bras Cir 2011; 38: 41-4.

2. Khamechian T, Alizargar J, Mazoochi T. 5-Year data analysis of patients following abdominal wall endometrioma surgery. BMC Womens Health 2014; 14: $151-4$

3. Jubanjik KJ, Comite F. Extrapelvic endometriosis. Obstet Gynecol Clin North Am 1997; 24: 411-40.

4. Nominato NS, Prates LF, Lauar I, Morais J, Maia L, Geber S. Cesarean section greatly increases risk of scar endometriosis. Eur J Obstet Gynecol Reprod Biol 2010; 152: 83-5

5. Ideyi SC, Schein M, Niazi M, Gerst PH. Spontaneous endometriosis of the abdominal wall. Dig Surg 2003; 20: 246-8.

6. Ding Y, Zhu J. A retrospective review of abdominal wall endometriosis in Shanghai, China. Int J Gynaecol Obstet 2013; 121: 41-4. 
7. Gunes M, Kayikcioglu F, Ozturkoglu E, Haberal A. Incisional endometriosis after cesarean section, episiotomy and other gynecologic procedures. J Obstet Gynaecol Res 2005; 31: 471-5.

8. Horton JD, Dezee KJ, Ahnfeldt EP, Wagner M. Abdominal wall endometriosis: a surgeon's perspective and review of 445 cases. Am J Surg 2008; 196: 207-12.

9. Vellido-Cotelo R, Muñoz-González JL, Oliver-Pérez MR, de la Hera-Lázaro C, Almansa-González C, Pérez-Sagaseta C, et al. Endometriosis node in gynaecologic scars: a study of 17 patients and the diagnostic considerations in clinical experience in tertiary care center. BMC Womens Health 2015; 15: 13.

10. Ecker AM, Donnellan NM, Shepherd JP, Lee TT. Abdominal wall endometriosis: 12 years of experience at a large academic institution. Am J Obstet Gynecol $2014 ; 211: 363$

11. Jamabo RS, Ogu RN. Abdominal scar endometriosis. Indian J Surg.2008; 70: 184-7.

12. Solak A, Genç B, Yalaz S, Sahin N, Sezer TÖ, Solak I. Abdominal wall endometrioma: ultrasonographic features and correlation with clinical findings. Balkan Med J 2013; 30: 155-60.

13. Ozel L, Sagiroglu J, Unal A, Unal E, Gunes P, Baskent E, et al. Abdominal wall endometriosis in the cesarean section surgical scar: a potential diagnostic pitfall. J Obstet Gynaecol Res 2012; 38: 526-30.

14. Kaplanoglu M, Kaplanoğlu DK, Ata CD, Buyukkurt S. Obstetric scar endometriosis: retrospective study on 19 cases and review of the literature. International Scholarly Research Notices 2014; 1-6.

15. Pachori G, Sharma R, Sunaria RK, Bayla T. Scar endometriosis: Diagnosis by fine needle aspiration. J Cytol 2015; 32: 65-7.
16. Hensen JH, Van Breda Vriesman AC, Puylaert JB. Abdominal wall endometriosis: clinical presentation and imaging features with emphasis on sonography. AJR Am J Roentgenol 2006; 186: 616-20.

17. Cöl C, Yilmaz EE. Cesarean scar endometrioma: Case series. World J Clin Cases 2014; 16: 133-6.

18. Medeiros Fd, Cavalcante DI, Medeiros MA, Eleutério J Jr. Fine-needle aspiration cytology of scar endometriosis: study of seven cases and literature review. Diagn Cytopathol 2011; 39: 18-21.

19. Veda P, Srinivasaiah M. Incisional endometriosis: Diagnosed by fine needle aspiration cytology. J Lab Physicians 2010; 2: 117-20.

20. Hughes ML, Bartholomew D, Paluzzi M. Abdominal wall endometriosis after amniocentesis. A case report. J Reprod Med 1997; 42: 597-9.

21. Chiang DT, Teh WT. Cutaneous endometriosis. Surgical presentations of a gynaecological condition. Aust Fam Physician 2006; 35: 887-8.

22. Kokuba EM, Sabino NM, Sato H, Aihara AY, Schor E, Ferreira LM. Reconstruction technique for umbilical endometriosis. Int J Gynaecol Obstet 2006; 94: 37-40.

23. Wang PH, Juang CM, Chao HT, Yu KJ, Yuan CC, Ng HT. Wound endometriosis: risk factor evaluation and treatment. J Chin Med Assoc 2003; 66: 113-9.

24. Wasfie T, Gomez E, Seon S, Zado B. Abdominal wall endometrioma after cesarean section: a preventable complication. Int Surg 2002; 87: 175-7.

25. Teng CC, Yang HM, Chen KF, Yang CJ, Chen LS, Kuo CL. Abdominal wall endometriosis: an overlooked but possibly preventable complication. Taiwan J Obstet Gynecol 2008; 47: 42-8. 